\title{
The Turbellaria of Plymouth Sound and the Neighbourhood.
}

\author{
By
}

\section{F. W. Gamble, B.Sc.,}

Berkeley Fellow of Owens College, Manchester.

I PROPOSE in this paper to furnish a list of the marine Turbellaria of Plymouth Sound and the neighbourhood, including all species that have hitherto been recorded from this locality. That such an attempt is in some respects premature I am only too well aware, but I have written it for the convenience of those who are working at, or are interested in, the fauna of Plymouth, and it may serve as a starting-point in our knowledge of the Turbellaria of the Sound. The synonymy and descriptions of the species are given by v. Graff, Lang, Jensen, and recently, together with figures of the new species and the literature, by myself.*

During August and September of 1892 I occupied a British Association table at the Laboratory, Plymouth, and commenced an investigation into the Turbellaria of the Sound. This was practically an unworked field. Montagu had indeed discovered Prostheceræus vittatus in Kingsbridge Estuary, South Devon, in 1815 : the Channel Islands have been partially explored with regard to the Turbellaria : St. Malo and St. Vaaste-la-Hogue have been still more carefully explored by Quatrefages, Keferstein, and Claparède. These researches, however, deal almost exclusively with the Polycladida. Hence it is only recently, through the investigations of Professor Hallez, that the Rhabdocœlida have received due attention at Wimereux and in the Strait of Dover. Professor Hallez's results are not yet quite complete, and I much regret my inability to consult the original papers. $\dagger$

The general results of my observations may be here briefly summarised. As one might have expected, a number of Mediterranean forms were noticed (about 18 per cent.). These, together with certain Scandinavian and a few new species, form the additions to

* British Marine Turbellaria, Quart. Journ. Micros. Sci., April, 1893.

† Revue biologique du nord de la France, Lille, 1890-2. 
the fauna. I should state that for several reasons my attention was directed more particularly to the Rhabdocœlida, consequently the number of Polycladida here recorded will, in all probability, be increased by future investigation.

As regards the methods of collecting the Turbellaria, it is necessary to bear in mind that almost all the Rhabdocœlida are so minute (rarely more than $2 \mathrm{~mm}$. in length) as to render it a matter of the greatest difficulty to isolate them from the tangled masses of seaweed in which they are usually found. My method of working the area between tide-marks was twofold. I collected the Ulva, Ptilota, Bryopsis, and other weeds, and placed them in vessels of sea water in the Laboratory. The Rhabdocœles emerged in great numbers, especially towards night, and could be picked out with a pipette. Stones richly coated with ascidians, polyzoa, sponges, \&c., and the sand- and shell-débris at the base of Corallina, treated in a similar manner, were very productive. The drawback to this method is that the real habitat of any particular species cannot thus be determined ; and although I attempted to isolate the various kinds of seaweeds I was not successful in establishing a constant relation between a Turbellarian and the plant on which it is found.

My second method was that proposed to me by David Robertson, Esq. It consisted in the use of a hand-net, in the mouth of which a sieve was placed to prevent the entrance of bulky weeds. Such a net was used from the dinghy at low water among the Laminaria, Halydris, \&c., which border the creeks in Wembury Bay, the Breakwater, and other places. Tide-pools were also explored by its help. The dredge brought up a large number of interesting forms. Millbay Channel, the Hamoaze, the Duke Rock, and the New Grounds are especially productive in infra-littoral forms. Examination of dredge-material at night gives one a vivid idea of the activity and voracity of this group. Pelagic forms were rare, and chiefly represented by the larvæ of Leptoplana and Müller's larvæ. The latter were specially abundant in October.

\section{Distribution of Turbellaria in Zones of Depth.}

First Zone.-This zone is usually uncovered for one to two days during neap-tides. Monotus fuscus is here the characteristic form, although it ranges throughout the tidal zone. It appears to derive moisture from Balani into which it creeps during ebb-tide. Other interesting devices for gaining moisture are recorded by Hallez and v. Graff. Towards the lower portion of this zone Convoluta paradoxa occurs. 
Second or Mid-tidal Zone.-This zone, daily covered by the tide, is characterised by the two species already mentioned, and also the following :-Aphanostoma diversicolor, Byrsophlebs graffi, Provortex balticus, Macrorhynchus naegelii, Plagiostoma vittatum, and Vorticeros auriculatum. Almost all these are provided with adhesive cells (Haftpapillen) at their posterior end, enabling them to retain their position during the wash of the tide.

Third Zone.-Exposed during spring-tides. Cylindrostoma quadrioculatum, Convoluta flavibacillum, Hyporhynchus armatus, Acrorhynchus caledonicus, Leptoplana tremellaris. This zone marks the lower limit of the Acœla, and of the great majority of Rhabdocœla.

Fourth Zone.-Depths up to 20 fathoms. Promesustoma solea, Provortex rubrobacillus, Cylindrostoma inerme, Plagiostoma girardi, species of Enterostoma, Stylostomum variabile, Oligocladus sanguinolentus, Eurylepta cornuta.

This sketch of the zones must be regarded as purely tentative, since my stay was not sufficiently prolonged to enable me to test these results. I was led to attempt such a classification from the striking absence of Acœla and most Rhabdocœla below the Laminarian zone. On this subject there appears to be very little published work, and it would be a matter of some interest to ascertain the alterations in the vertical distribution of Turbellaria according to the difference of surroundings and tidal conditions at various parts of the coast.

\section{Local Distribution of Turbeluaria.}

\section{Wembury Bay.}

My work in this bay has been restricted to an examination of the well-known collecting-ground exposed at low water below Wembury Church. So far as my experience goes, this appears to be (for Turbellaria) the richest locality in the neighbourhood of Plymouth. Nineteen species have occurred between tide-marks excluding four doubtfully new forms, which were either too rare or too immature for exact and thorough determination.

It is not easy to define the characteristic Turbellarian features of Wembury Bay. The abundance of Cylindrostoma quadrioculatum, C. inerme, Macrorhynchus naegelii, and Plagiostoma dioicum, together with five species of the Acœla, and the apparent absence of Monotidæ, lend a provisionally distinctive aspect.

The splendid tide-pools abounding in such algæ as Cystoseira ericoides, Codium tomentosum, Bryopsis plumosa, are the best huntinggrounds. Among sand at the base of Corallina officinalis, curious 
colour-varieties of Leptoplana tremellaris, specimens of Aphanostoma diversicolor, Convoluta paradoxa, Plagiostoma girardi (at low springtides), and an example of what appears to be Fovia affinis (a marine Triclad). In the tufts of matted Florideæ which hang from the under surface of rocks, Cylindrostoma quadrioculatum occurs in hundreds. Tow-netting in the narrow creeks that run in between the rocks produced young specimens of Leptoplana tremellaris, Convoluta paradoxa, Plagiostoma vittatum, and Cylindrostoma inerme. Working the Laminaria-fronds by a hand-net from the stern of the "Anton Dohrn" did not, however, add anything of interest.

There can be no doubt that many forms have been overlooked, and that if examined earlier in the year, Turbellaria differing from those occurring during the summer might be found. The following is a list of the species hitherto recorded:

Polycladida, Leptoplana tremellaris.

Tricladida, Fovia affinis.

\section{Rhabdocœlida.}

Accla, Proporus venenosus, Monoporus rubropunctatus, Aphanostoma diversicolor, Convoluta paradoxa, C. flavibacillum.

Rhabdoccla, Promesostoma marmoratum, Acrorhynchus caledonicus, Macrorhynchus naegelii, Hyporhynchus armatus, Provortex balticus.

Alløocєla, Plagiostoma dioicum, Pl. elongatum, Pl. vittatum, Pl. girardi, Enterostoma fingalianum, Cylindrostoma quadrioculatum, Cyl. inerme.

\section{Plymouth Breakwater.}

Of the two faces of the Breakwater I have naturally paid most attention to the inner one, the stones and weeds of which afford good collecting-ground during low spring-tides. Many of the weeds on the inner face have, during the summer, an unhealthy, half-decayed appearance, which is associated with the occurrence of certain Turbellaria. Psendorhynchus bifidus, however, which occurs typically in such a habitat in the Isle of Man and the east and west coasts of Scotland, has not yet occurred at Plymouth. Macrorhynchus naegelii and Plagiostoma koren $i$ are the characteristic forms of the Breakwater. The number of adult examples of the former species diminished from the beginning of August onwards, and Mr. Garstang sent me the largest he could find in November, but all, without exception, were quite immature. Stones, the cavities of which were occupied by anemones, brought from the Breakwater and kept for some time (six weeks to two

NEW SERIES,-YOL, III, NO. I. 
months) in the Laboratory, produced a number of Plagiostoma vittatum and $\mathrm{Pl}$. koreni. The pyriform stalked egg-capsules of the former were deposited in numbers in August. These and other species have the habit of creeping about under a covering of diatomdeposit which encrusts stones, weeds, \&c. Protected in this way they are extremely difficult to find.

My method of examining the Breakwater was chiefly the use of a hand-net, which was worked vigorously among the weeds at low water from the dinghy. By this means the following fauna were obtained :

Polycladida, Leptoplana tremellaris (adult and young).

\section{Rhabdocœlida.}

Accela, Aphanostoma diversicolor.

RHABDOCGLA, Macrorhynchus naegelii, Mesostoma (?) neapolitanum.

Alleoccela, Plagiostoma elongatum, Pl. koreni, Pl. vittatum, Vorticeros auriculatum and V. luteum, Allostoma pallidum, Monotus lineatus.

\section{Cawsand Bay.}

There are here two distinct collecting-grounds-the rocks and tide-pools exposed at low water on the north side of the bay towards Picklecombe Fort, and the beds of Zostera that grow on the sandy bottom. In the former locality Acrorhynchus caledonicus is the prevailing species, as Hyporhynchus armatus is the chief feature of the Zostera bed. It was only toward the end of my visit that I discovered the tiny Rhabdocœles among the Crustacea and Nemertea which occur in great quantity in the Zostera, so that many forms will probably be added by a re-examination of the dredgings taken among the rich weedy ground indicated by Prof. Johnson (the Journal [N. S.], I, iii, pp. 297-8).

In the following list $\mathrm{Z}$ refers to species inhabiting the Zostera beds, $\mathrm{N}$ to forms occurring in the rock-pools on the north side of the bay.

Polycladida, Oligocladus sanguinolentus (Z).

\section{Rhabdocœlida.}

ACELA, Proporus venenosus (Z), Monoporus rubropunctatus (Z), Convoluta saliens (Z), C. paradoxa (N), C. flavibacillum (Picklecombe Fort).

Rhabdoccla, Promesostoma solea (Z), P. agile (Z), Proxenetes flabellifer (N), Acrorhynchus caledonicus (N), Hyporhynchus 


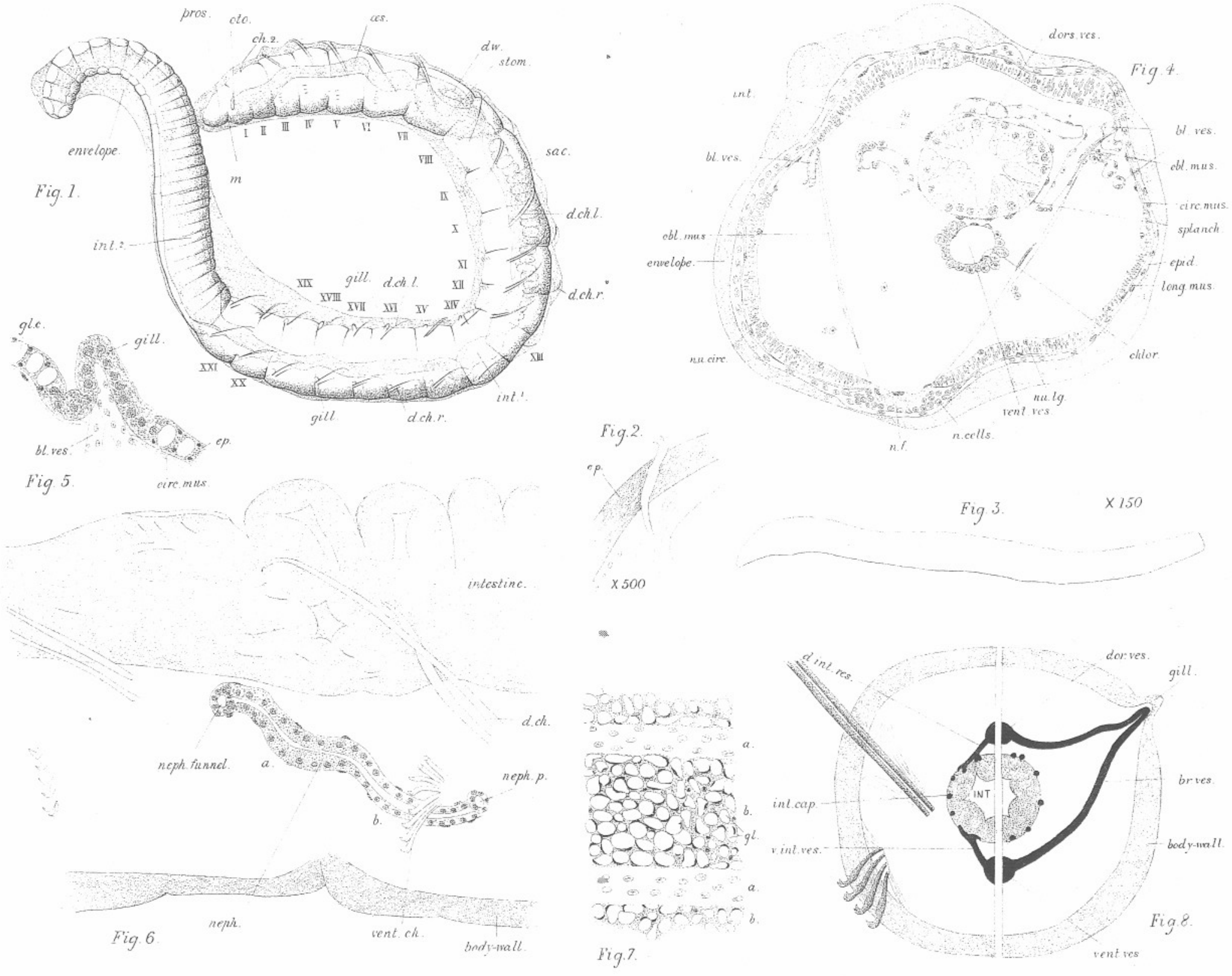


armatus (Z), H. (?) penicillatus (Z), Provortex affinis (N), P. rubrobacillus $(\mathrm{Z})$.

Alleocela, Plagiostoma vittatum (N and $\mathrm{Z}), P$. dioicum (N), $P$. girardi $(\mathrm{N})$, Monotus albus $(\mathrm{N})$.

New Grounds.

The Turbellaria of this part of the Sound (north of the west entrance to the Sound), like the flora, is similar to that of the Duke Rock. There is, however, a characteristic form (Provortex rubrobacillus) that has not occurred elsewhere in the neighbourhood. Macrorhynchus croceus and M. helgolandicus will probably be found in other parts of the Sound, although at present this is the only known locality for them.

Polycladida, Leptoplana tremellaris.

\section{Rhabdocœlida.}

Rhabdocela, Promesostoma solea, Macrorhynchus naegelii, $M$. croceus, M. helgolandicus, Provortex rubrobacillus.

Allegocela, Plagiostoma vittatum, Vorticeros luteum, Cylindrostoma inerme.

\section{Duke Rock.}

The Duke Rock, situated in 7 fathoms at the east entrance of the Sound, forms one of a number of dredging-grounds inside the Sound, the Turbellarian fauna of which has a common general facies. The conditions of life in these localities are different from those in the tidal zone, and the difference is expressed in the Turbellaria as well as in other groups of animals and plants. Thus Acœla are, so far as my experience goes, quite unrepresented; the Allœocœla, on the other hand, are abundant.

The Turbellaria of the Duke Rock closely resemble those of the New Grounds, and this similarity is also borne out in the flora (see Johnson, "Flora of Plymouth Sound," loc. cit., p. 291). The most interesting form was a single specimen of Monoophorum striatum (Böhmig) (= Enterostoma striatum, v. Graff), which has hitherto only occurred at Trieste. Its carmine colour and the appearance of the muscles grouped in longitudinal bundles at once attract attention.

Species of the genus Enterostoma (perhaps at present the most unsatisfactory genus of all Allœocœla) are abundant here and elsewhere in the Sound. As, however, I have not completed my revision of the genus, the species recorded are only part of those that were 
actually found. The following is a list of the Duke Rock Turbellaria :

Polycladida, Leptoplana tremellaris, Eurylepta cornuta, Stylostomum variabile.

\section{Rhabdocœlida.}

Rhabdocela, Promesostoma ovoideum, Pr. solea.

Alleocela, Plagiostoma dioicum, Pl. girardi, Enterostoma austriacum, Cylindrostoma inerme, Monoophorum striatum, Automolos unipunctatus.

\section{Drake's Island.}

The well-known collecting-ground on the north-eastern face of this locality has furnished the following fauna. The great belt of Laminaria extending in the direction of the Breakwater did not add anything of interest.

Polycladida, Leptoplana tremellaris, adult and young ( $3 \mathrm{~mm}$. long).

\section{Rhabdocœlida.}

ACœLA, Proporus venenosus, Monoporus rubropunctatus, Convoluta paradoxa.

Rhabdoccela, Promesostoma marmoratum, Pr. solea, Pr. agile, Byrsophlebs intermedia, Byr. graffi, Acrorhynchus caledonicus, Macrorhynchus naegelii (Claparède's variety with dorsal yellow streak), Provortex affinis.

AlleOcøla, Plagiostoma vittatum, Vorticeros auriculatum, Cylindrostoma quadrioculatum (also on the S.E. face of the island).

\section{Redding Point.}

By this locality I include the shore from Redding Point to northward under Mount Edgeumbe Park. This area is prolific in littoral forms, the tide-pools and rocks being covered with a profusion of animal and vegetable life. Promesostoma marmoratum, Monotus fuscus, and $M$. lineatus are the prevalent forms, the two latter species being particularly abundant among the Ulva that covers the stones. The use of a hand-net in the tide-pools needs some discretion, since the crustacean Virbius varians swarms to such an extent as to exclude almost everything else. To get over this difficulty it is necessary to employ a fine sieve, as described in the introduction.

A comparison of the Turbellarian fauna with that of other parts 
of the Sound cannot yet be made justly, as my investigations are not yet sufficiently complete. The Turbellaria appear to resemble those of the Breakwater, as a comparison of the accompanying tables tends to show. Specially interesting forms are Aphanostoma elegans, hitherto recorded from Bergen, and Plagiostoma sagitta, found by Uljanin in the Bay of Sebastopol. The occurrence of species from such widely distant localities shows how much still remains to be done before we can determine the geographical distribution of the species of this group.

The following list of species were taken at low water round Redding Point and northwards :

Polycladida, Stylostomum variabile ( $75 \mathrm{~mm}$. long).

\section{Rhabdocœlida.}

Acøla, Convoluta paradoxa, Aphanostoma elegans.

Rhabdoccla, Microstoma grœnlandicum, Promesostoma marmoratum, Pr. solea, Acrorhynchus caledonicus, Macrorhynchus naegelii, Hyporhynchus armatus, Provortex balticus.

Alleocela, Plagiostoma vittatum, Pl. koreni, Pl. sagitta, Vorticeros auriculatum, Monotus lineatus, M. fuscus.

\section{East Side of the Sound.}

Under this heading I include the rocks below the Laboratory, Rum Bay, Batten Bay, and Bovisand Bay. As regards the Turbellaria of the first three there is little to be said. The same causes that have impoverished the flora and fauna probably account for the poor result in this group. Repeated attempts only resulted in Convoluta paradoxa, Plagiostoma vittatum, Vorticeros auriculatum, and Monotus fuscus. The last also occurs on the rocks below the ladies' bathingplace. In Bovisand Bay the tide-pools yielded Convoluta paradoxa and C. flavibacillum.

\section{The Hamoaze.}

A portion of this locality was explored by the help of the "Firefly." The stones and débris that are brought up are covered with the mudtubes of Polydora cæca, tenanted, however, by an Amphipod, Corophium Bonellii. The great abundance of this Crustacean possibly in part accounts for the limited Turbellarian fauna.

Polycladida, Leptoplana tremellaris.

\section{Rhabdocœlida.}

Alleocela, Plagiostoma pseudomaculatum, Oylindrostoma inerme, Automolos (?) ophiocephalus, Aut. horridus. 


\section{Millbay Channel.}

This channel (varying in depth from 18 to 21 fathoms) is a recognised locality for certain animals, and I have found some species of Turbellaria peculiar to it. The allœocœlous fauna of this channel and the Hamoaze present an interesting species of the genus Automolos, apparently connecting the Allœocœla with the Tricladida. More observations are however needed, and an examination of these two localities will probably forward the solution of this problem. Species of Cylindrostoma and Enterostoma make up the bulk of the fauna. A specimen of what I take to be Plagiostoma siphonophorum (if confirmed) will prove to be another Adriatic form added to the Plymouth fauna.

Polycladida, Leptoplana tremellaris (abundant), Oligocladus sanguinolentus, Stylostomum variabile (young stages, $5-1 \mathrm{~mm}$., are not uncommon in September).

\section{Rhabdocœlida.}

RHAbdoccla, Promesostoma solea.

Alleocala, Plagiostoma siphonophorum (?), Pl. girardi, Enterostoma fingalianum, E. austriacum, Automolos ophiocephalus.

\section{SYSTEMATIC LIST OF THE TURBELLARIA.*}

\section{TURBELLARIA.}

\section{Sub-order 1.-RHABDOCOELIDA.}

A. $A O E L L A$.

Family PROPORIDÆ.

Gemus 1.-Proporus.

1. Proporus venenosus (O. Schmidt).

This species is readily distinguished from all other Acœla by its elongate form, yellow colour, and large eyes. It is not uncommon at the base of the littoral zone at Wembury Bay and Drake's Island.

* A key for the determination of genera and species may be found in my "British Marine Turbellaria,"' loc. cit., pp. 514-522. 


\section{Genus 2.-Monoporus.}

2. Monoporus rubropunctatus (O. Schmidt).

Found in the same localities as the foregoing. Both are Mediterranean species.

\section{Family APHANOSTOMID $Æ$.}

Genus 3.-Aphanostoma.

\section{Aphanostoma diversicolor Oersted.}

In various localities between tide-marks. Not uncommon in the diatom-deposit on the sides of the tanks in the aquarium.

4. Aphanostoma elegans Jensen.

A single specimen amongst Ulva at Redding Point.

\section{Genus 4.-Convoluta.}

5. Convoluta saliens v. Graff.

This species is apparently rather rare at Plymouth. Among Zostera from Cawsand Bay is the habitat for it. The curious mode of progression by sudden leaps, which co-exists along with the usual method of continuous movement, was first described by v. Graff in his "Monograph," and is apparently unique.

\section{Convoluta paradoxa Oersted.}

Widely distributed in the littoral zone; nowhere, however, very abundant, nor do the specimens attain the dimensions of Millport examples.

\section{Convoluta flavibacillum Jensen.}

Among sand in the creeks at Picklecombe Fort, Wembury Bay, and Bovisand Bay. 


\section{B. RHABDOCELIDA.}

\section{Family MICROSTOMID $Æ$.}

Genus 5.-Microstoma.

8. Microstoma grenlandicum Lev.

Among Ulva, Redding Point.

Family MESOSTOMIDÆ.

Genus 6.-Promesostoma.

9. Promesostoma marmoratum (Schultze).

Variable in coloration and in the form and dimensions of the crosier-like copulatory organ. Not uncommon in tide-pools in Wembury Bay, Drake's Island, and Redding Point.

10. Promesostoma ovoideum (0. Schmidt).

Occasionally dredged near the Duke Rock.

11. Promesostoma solea (O. Schmidt).

Abundant in dredging taken from almost all localities.

12. Promesostoma agile (Levinsen).

Among Zostera in Cawsand Bay.

\section{Genus 7.-Byrsophlebs.}

13. Byrsophlebs graffi Jensen.

Drake's Island, low spring-tide. Amongst algæ.

14. Byrsophlebs intermedia v. Graff.

In the same locality as the foregoing.

Genus 8.-Proxenetes.

15. Proxenetes flabellifer Jensen.

In tide-pools on the north side of Cawsand Bay. 


\section{Gemus 9.-Mesostoma.}

16. Mesostoma neapolitanum v. Graff (?).

A single specimen obtained among Fuci bordering the inner side of the Breakwater. This species hitherto recorded only from the Mediterranean.

\section{Family PROBOSCIDÆ.}

\section{Genus 10.-ACRORHYNCHUS.}

17. Agrorhynchus caledonicus (Claparède).

Found in abundance among Fucus, Halydris, \&c., in tide-pools near Picklecombe Fort and Redding Point; less commonly in Wembury Bay.

\section{Genus 11.-MACroRHynchUS.}

18. Macrorhynchus naegeim (Kölliker).

On the inner side of the Breakwater at low spring-tides this species was found plentifully during August.

19. Macrorhynchus croceus (Fabricius).

Dredged on one occasion on the "New Grounds."

20. Macrorhynchus helgolandicus (Metschnikoff).

In the same locality as the foregoing. Probably a search instituted earlier in the year would reveal more localities for these two species. Only a few adults were found, usually each with a single egg-capsule.

\section{Genus 12.-HyporHynchUs.}

21. Hyporhynchus armatus (Jensen).

Abundant among Zostera in Cawsand Bay and in tide-pools at Redding Point.

22. Hyporhynchus penicillatus (Schmidt).

A single specimen among Zostera, Cawsand Bay. 


\section{Family VORTICID A. \\ Gemus 13.-Provortex.}

23. Provortex balticus (Schultze).

This species is apparently not common at Plymouth during August and September. It occurs between tide-marks, most commonly in Wembury Bay.

24. Provortex afrinis (Jensen).

Among algæ on the north- and south-eastern faces of Drake's Island.

25. Provortex rubrobacillus, Gamble.

This form is figured and described in my "British Marine Turbellaria," pp. 470-1, pl. xxxix, fig. 8, and pl. xl, fig. 12. The constant presence of red, rod-like concretions in the intestinal cells and the form of the copulatory organ are diagnostic features.

C. ALLEOCELA.

Family PLAGIOSTOMIDA.

Gemus 14.-Plagiostoma.

26. Plagiostoma dioicum (Metschnikoff).

Duke Rock and Wembury Bay.

27. Plaglostoma elongatum Gamble ("British Marine Turbellaria," p. 473).

A single specimen among sand, Wembury Bay. Mr. Garstang sent me two from the Breakwater in November.

28. Plagiostoma pseddonaculatum Gamble (loc. cit., p. 474).

Among the weed-tubes of Polydora cæca in the Hamoaze.

29. Plagiostoma sagitta Uljanin.

Among weeds in a tide-pool, Redding Point.

30. Plagiostoma caudatum Levinsen.

A single specimen dredged in Cawsand Bay among Zostera. 
31. Plagiostoma vittatum (Frey u. Leuckart).

An abundant littoral species in all localities. The variations in colour are great, and are discussed by v. Graff and myself. Eggcapsules were obtained from the Breakwater in September.

32. Plagiostoma koreni Jensen.

Among algæ on the Breakwater and at Redding Point, also among diatom-deposit in the tank-room of the Laboratory.

33. ? Plagiostoma siphonophordm (Schmidt).

A specimen in the Millbay Channel. (See "Brit. Mar.Turbellaria," p. 477.)

34. Plagiostoma girardi (Schmidt).

At extremely low spring-tide, Wembury Bay, and in tide-pools on the north side of Cawsand Bay. Not uncommon on the Duke Rock and in Millbay Channel.

\section{Genus 15.-Vorticeros.}

35. Vorticeros adriculatum (O. F. Müller).

Found in the same localities and under the same conditions as Plagiostoma vittatum.

36. Vorticeros lutedi v, Graff.

A single specimen dredged off the New Grounds; another obtained on the inner side of the Breakwater.

\section{Gemus 16.-Enterostoma.}

37. Enterostoma austriacum v. Graff.

Specimens referable to this species occurred commonly in the Sound at depths below 5 fathoms.

38. Enterostoma fingalianum Claparède.

Among Florideæ, Wembury Bay.

\section{Genus 17.-Cylindrostoma.}

39. Cruindrostoma quadrioculatum (R. Leuckart).

Abundant in the same locality as the preceding. 
40. Cylindrostoma inerme (Hallez).

In dredgings taken from the Duke Rock, Millbay Channel, and the Hamoaze.

41. Cylindrostoma elongatum Levinsen.

Tide-pools, Wembury Bay.

\section{Gemus 18.-MonoopHorum.}

42. Monoophorum striatum (v. Graff).

A single specimen of this characteristic species was dredged off the Duke Rock.

\section{Family MONOTID压. \\ Genus 19.-Monotus.}

43. Monotus lineatus (O. F. Müller).

Not uncommon amongst Ulva in the neighbourhood of Redding Point.

44. Monotus fuscus (Oersted).

Abundant among Balani, Ulva, and generally throughout the littoral zone.

45. Monotus albus Levinsen.

In tide-pools below Picklecombe Fort.

Genus 20.-Аитомоциs.

46. Automolus unipunctatus (Oersted).

Rarely amongst algæ, Duke Rock.

47. Automolos horridus Gamble ("British Marine Turbellaria," p. 491).

A single specimen in the Hamoaze.

48. (?) Automolos ophiocephatus (Schmidt).

Millbay Channel. For a discussion of the probable relations of this form see my paper, pp. 492-3. 


\title{
Sub-order 2.-TRICLADIDA.
}

\author{
Family PLANARIIDA.
}

Genus 21.-Fovia.

49. Fovia affinis Stimpson.

In a sandy creek, Wembury Bay.

\section{Sub-order 3.-POLYCLADIDA.}

\author{
A. ACO'TYLEA. \\ Family PLANOCERIDA.
}

Gemus 22.-Leptoplana.

50. Leptoplana tremellaris (O. F. Müller).

I have recently ascertained that many examples grouped under this species, on the ground of their general agreement with the type in form, colour, and the number and position of the eye-groups, in reality belong to the next species. The subject requires further investigation, which, owing to the pressure of other work, I am unable to undertake at present. The specific characters and synonymy of this form are given fully by Lang in his "Polycladida," and the previous records on our coast in my "British Marine Turbellaria."

Adult examples occur generally at Plymouth, under stones and shells from the littoral zone down to 15 fathoms. They are plentiful during July and August, becoming scarcer in September. Mr. Garstang informs me that the species during February is difficult to discover even in its summer haunts. It is tolerably certain that, like the majority of littoral animals, the adults die in the autumn, and the young probably attain sexual maturity in the following summer.

Copulation in this species has not hitherto been observed. The eggs are laid in successive batches, surrounded by an albuminous substance. They adhere to stones, algæ, \&c., between tide-marks, and after a period varying from a fortnight (Keferstein) to two months (Hallez) the larvæ hatch out. Specimens 1 to $3 \mathrm{~mm}$. in length, and having the outline of a spherical triangle, were fairly abundant in the littoral zone in September. Thus at Wembury Bay and inside the Breakwater many specimens were obtained with the aid of the 
hand-net among Laminaria, Corallina, \&c. A few specimens also occurred in tow-nettings taken close inshore and also in mid-channel, outside the Breakwater. At present I am unable to state whether these young Leptoplana belong to either or both of the species here recorded. The genital ducts afford the only secure diagnostic features, and naturally these are wanting in the present instance.

\section{Leptoplana Drebachensis Oersted.}

In my paper previously cited I have discussed the possible identity of this species with the older L. atomata, O. F. M.

Recently, specimens from Plymouth Sound have reached me which agree in almost every particular with $L$. Droebachensis, Oe., as described by Jensen, and it appears probable that this species has hitherto been confused on our coasts with $L$. tremellaris. The old species, $L$. atomata, O. F. M., whose relations with other species of the genus are totally obscure, might perhaps be dropped altogether.

\section{B. OOTYLEA.}

\section{Family EURYLEPTID丑.}

Gemus 23.-Prostheceraed.

52. Prosthecerafus vittatus (Montagu).

This fine species, discovered by Montagu in the estuary of Kingsbridge, has occurred off Stoke Point on Diazona in 15 fathoms (Mr. Cunningham), and also in the Sound (Mr. Garstang).

\section{Genus 24.-Cycloporus.}

53. Crcloporus papillosus Lang.

Infra-littoral specimens have occurred on ascidians and sponges (e.g. Hymeniacidon sanguinea) dredged in the Cattewater, and also outside the Sound. The variety lævigatus occurred along with Stylostomum variabile (to which it bears no little resemblance) in the river Yealm in October. The relations which appear to exist between this species and the substratum in which it lives are discussed by me in the forthcoming number of the Transactions of the Liverpool Biological Society. 
Genus 25.-Eurylepta.

54. Eurylepta corndta (O, F. Müller).

Occasionally dredged on the Duke Rock and in the estuary of the Yealm.

Genus 26.-Oligocladus.

55. Oligocladus sanguinolentus (Quatrefages).

Adult specimens were dredged off the Duke Rock, Millbay Channel, Cawsand Bay, and Stoke Point.

\section{Genus 27.-SтүLosтomum.}

56. Stylostomum variabile Lang.

Estuary of the Yealm, Duke Rock. Young stages were found between tide-marks at Redding Point and round the Mallard Buoy in September. 